American Journal of Applied Sciences 5 (4): 440-453, 2008

ISSN 1546-9239

(C) 2008 Science Publications

\title{
A Comparative Study of the Purification of Aquaculture Wastewater Using Water Hyacinth, Water Lettuce and Parrot's Feather
}

\author{
A. M. Snow and A. E. Ghaly \\ Process Engineering and Applied Science Department \\ Dalhousie University, Halifax, Nova Scotia, Canada B3J 1Z1
}

\begin{abstract}
Water hyacinth, water lettuce and parrot's feather plants were examined for their ability to remove nutrients from aquaculture wastewater at two retention times. During the experiment, the aquatic plants grew rapidly and appeared healthy with green color. At hydraulic retention times (HRTs) of 6 and 12 days, the average water hyacinth, water lettuce and parrot's feather yields were 83, 51 and $51 \mathrm{~g}(\mathrm{dm}) \mathrm{m}^{-2}$ and 49,29 and $22 \mathrm{~g}(\mathrm{dm}) \mathrm{m}^{-2}$, respectively. The aquatic plants were able to significantly reduce the pollution load of the aquaculture wastewater. The TS, COD, $\mathrm{NH}_{4}{ }^{+}-\mathrm{N}, \mathrm{NO}_{2}{ }^{-}-\mathrm{N}$, $\mathrm{NO}_{3}{ }^{-} \mathrm{N}$ and $\mathrm{PO}_{4}{ }^{3-}-\mathrm{P}$ reductions ranged from 21.4 to $48.0 \%$, from 71.1 to $89.5 \%$, from 55.9 to $76.0 \%$, from 49.6 to $90.6 \%$, from 34.5 to $54.4 \%$ and from 64.5 to $76.8 \%$, respectively. Generally, the reductions increased with longer retention times and were highest in compartments containing water hyacinth followed by compartments containing water lettuce and parrot's feather. In terms of COD, $\mathrm{NO}_{3}{ }^{-}-\mathrm{N}$ and $\mathrm{PO}_{4}{ }^{3-}-\mathrm{P}$, the effluent leaving the hydroponics system was suitable for reuse in aquaculture. However, the effluent had slightly high levels of TS, $\mathrm{NH}_{3}-\mathrm{N}, \mathrm{NO}_{2}^{-}-\mathrm{N}$ and $\mathrm{pH}$ after treatment.
\end{abstract}

Keywords: aquaculture, wastewater, water hyacinth, water lettuce, parrot's feather, water quality

\section{INTRODUCTION}

Aquaculture has become the fastest growing food production sector in the world. The industry has grown at an average rate of $8.9 \%$ per year since 1970 , compared with only $1.2 \%$ for capture fisheries and $2.8 \%$ for livestock production systems ${ }^{[1]}$. However, the industry places great demands on water resources, and typically requires anywhere from $200-600 \mathrm{~m}^{3}$ of water for every kilogram of fish produced ${ }^{[2]}$. Although some aquaculture systems (raceways and pond culture) are much more water consumptive than others (recirculating systems), the industry generally requires more water per unit area or per unit of product than most other plant or animal production systems ${ }^{[3]}$. Consequently, aquaculture operations produce large quantities of effluent containing particulate and dissolved organic matter and nutrients that requires treatment and/or disposal. The production of 1 tonne of channel catfish releases an average of $9.2 \mathrm{~kg}$ of nitrogen, $0.57 \mathrm{~kg}$ of phosphorus, $22.5 \mathrm{~kg}$ of BOD and $530 \mathrm{~kg}$ of settleable solids into the environment ${ }^{[4]}$. Therefore, aquaculture effluents exert adverse environmental impacts when discharged to receiving waters as organic matter loading reduces dissolved oxygen levels and contributes to the buildup of bottom sediments and high nutrient loading stimulates excessive phytoplankton production ${ }^{[5,6]}$.

Numerous aquatic macrophytes have demonstrated considerable potential for nutrient removal from various types of wastewaters ${ }^{[6-9]}$. Remediation of wastewater occurs by various physical, biological and chemical mechanisms including: settling of suspended solids, adsorption and ion exchange, breakdown, uptake and transformation of contaminants by microorganisms, fungi and plants and precipitation and chemical fixation reactions ${ }^{[10]}$. The plants enhance wastewater treatment by acting as a medium for bacterial growth, by filtering/adsorbing suspended particulate matter and by removing inorganic nutrients from the wastewater ${ }^{[9]}$.

The primary aim of this study was to evaluate the feasibility of using three macrophytes (water hyacinth, water lettuce and parrot's feather) to purify the wastewater from an aquaculture operation. The specific objectives were to evaluate: (a) the effect of retention time on plant growth, (b) the effectiveness of these plants in reducing the pollution load of the aquaculture wastewater as measured by $\mathrm{TS}, \mathrm{COD}, \mathrm{NH}_{4}{ }^{+}-\mathrm{N}, \mathrm{NO}_{2}{ }^{-} \mathrm{N}$,

Corresponding author: Professor A. E. Ghaly, Process Engineering and Applied Science Department, Dalhousie University, Halifax, Nova Scotia, Canada; Tel: (902) 494-6014; Fax: (902) 420-7639 
$\mathrm{NO}_{3}^{-}-\mathrm{N}, \mathrm{PO}_{4}{ }^{3-}-\mathrm{P}$ and $\mathrm{pH}$ and (c) the suitability of recycling the treated wastewater for fish culture.

\section{EXPERIMENTAL APPARATUS}

The hydroponic system (Fig. 1) consisted of a frame, growth troughs and aeration, lighting, cooling, irrigation, supernatant collection and control units.

The frame (Fig. 2) was constructed of angle iron with a width of $244 \mathrm{~cm}$, a depth of $41 \mathrm{~cm}$ and a height of $283 \mathrm{~cm}$. The back and the top were covered with 0.6 $\mathrm{cm}$ thick plywood sheets. The frame consisted of three shelves (76 cm apart). Each shelf was divided vertically into two cells by dividers made of $1.2 \mathrm{~cm}$ thick plywood sheets. The frame supported the growth troughs and all other systems.

The plant growth unit consisted of six troughs. Each trough was made of galvanized steel and was divided into three compartments. Each compartment held a tray that acted as the plant support medium and consisted of a wire-mesh base (16 openings $\mathrm{cm}^{-2}$ ) with $5 \mathrm{~cm}$ high metal sides. The dimensions of each trough and plant supporting tray are shown in Figure 2. The trays were positioned in the troughs so that the plant roots were in contact with the liquid waste. The placement of trays was maintained by means of supports welded into the corners of each compartment 5 $\mathrm{cm}$ below the top edge of the trough.

An aeration unit was installed in each compartment to provide oxygen to the immersed roots of the growing plants. The main air supply was connected to a manifold (PVC pipe of $2.54 \mathrm{~cm}$ outside diameter) on each shelf using PVC tubing of $0.635 \mathrm{~cm}$ outside diameter. The air flow from the main supply to the manifold on each shelf was controlled by a pressure regulator (Model 129121-510, Aro, Brayn, OH). Six aeration units were connected to the manifold on each shelf using PVC tubing of $0.635 \mathrm{~cm}$ outside diameter. Each aerator consisted of a main tube with three perforated stainless steel laterals coming off it at right angles to the main. Each lateral was approximately 30 $\mathrm{cm}$ long whereas the main was $26.5 \mathrm{~cm}$ long.

The lighting unit was designed to provide approximately 360 hectolux of illumination per trough. This was achieved by a mixture of fluorescent and incandescent lamps. Six $34 \mathrm{~W}$ cool white fluorescent lamps (122 cm in length) and two $60 \mathrm{~W}$ Plant Gro N Show bulbs were fastened above each trough.

A cooling unit was designed to continuously remove the heat produced by the lamps to avoid heating of the wastewater on the upper and middle shelves. For each of these two shelves, a $5 \mathrm{~cm}$ diameter PVC pipe,

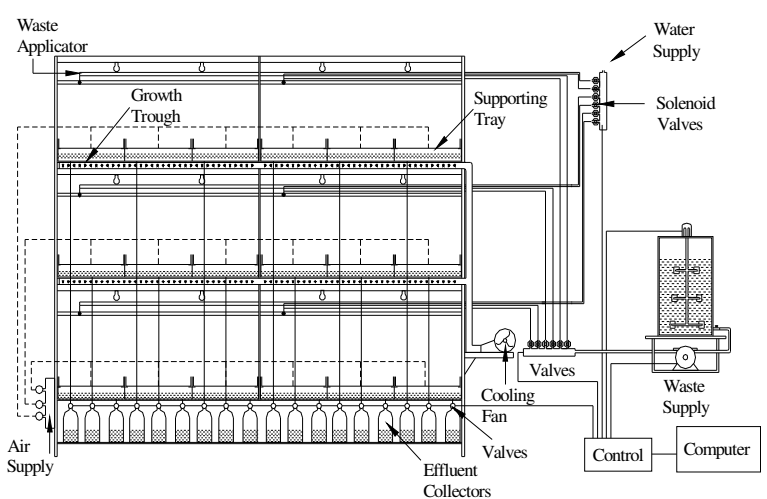

Fig. 1: The hydroponics system
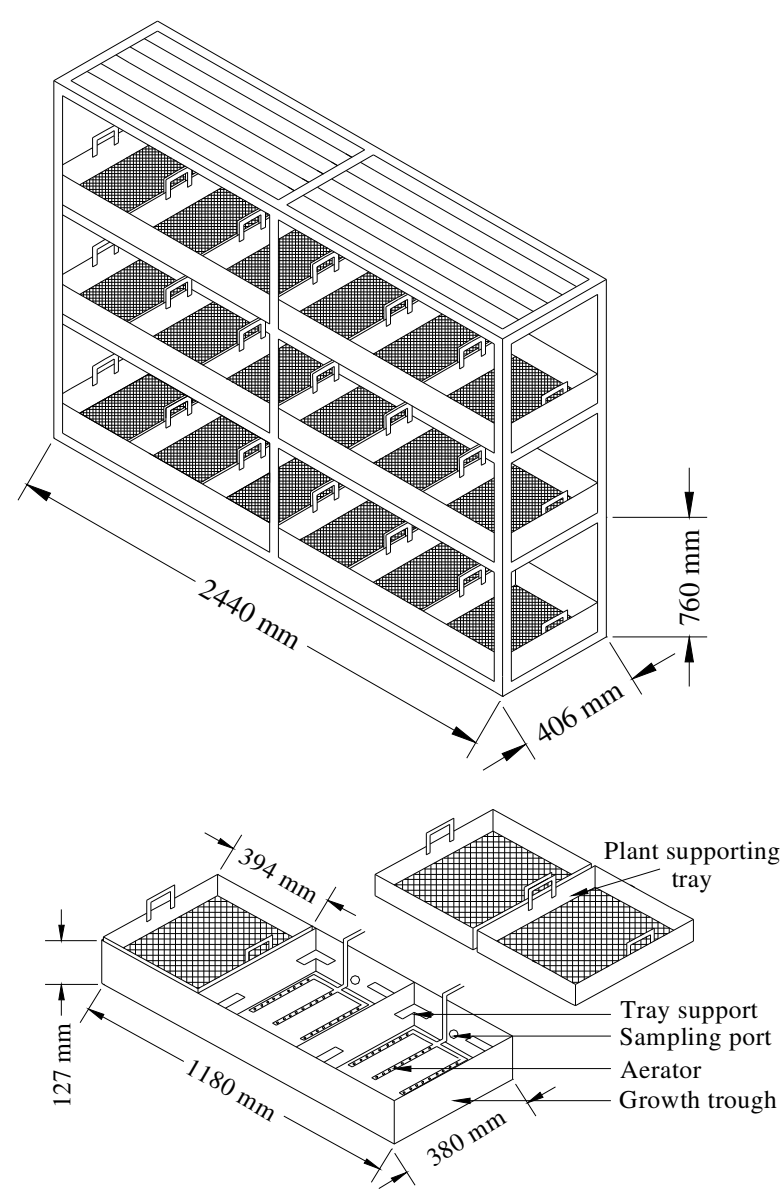

Fig. 2: The frame, growth trough and plant support tray

having $6 \mathrm{~mm}$ diameter holes spaced $6 \mathrm{~cm}$ apart and facing out, was placed under the backside of the troughs.

Two metal blocks supported the front side of the trough. This provided a $5 \mathrm{~cm}$ space between the trough and the lighting unit of the shelf below it. A $5 \mathrm{~cm}$ 
diameter PVC pipe acting as a manifold was attached vertically to the left side of the frame, through which air was blown by means of a motor driven fan (Model AK4L143A type 821, Franklin Electric Company, Bluffton, IN).

The wastewater application unit consisted of: (a) a wastewater storage tank, for storing the wastewater, (b) a pump, to transfer the wastewater from the storage tank to the growth troughs, (c) six valves, to control the amount of wastewater fed to each cell and (d) an irrigation system, for applying the wastewater onto the plant supporting trays in the growth troughs. The wastewater storage tank was constructed of plastic and had a capacity of approximately 100 L. A mixing shaft, with a $40 \mathrm{~cm}$ diameter impeller, was installed through the center of the cover of the tank to agitate the wastewater in the tank. Four $2.5 \mathrm{~cm}$ baffles were installed vertically along the inside wall of the tank to promote complete mixing. A $1 \mathrm{hp}$ motor (Model NSI10RS3, Bodine Electric Company, Chicago, IL) with speed reducer was mounted on the tank cover to drive the mixing shaft and impeller. The wastewater storage tank was connected to the pump using TYGON tubing of $3.175 \mathrm{~cm}$ outside diameter. A variable speed pump (Model 110-23E, TAT Pumps Inc., Logan, OH) with a capacity of $138 \mathrm{~cm}^{3} \mathrm{rev}^{-1}$ was used to transfer the wastewater from the storage tank to the irrigation system. The pump was connected to the irrigation system using PVC tubing of $1.905 \mathrm{~cm}$ outside diameter. Six valves were used to control the amount of wastewater fed to each growth trough. The timing and duration of opening/closing of the valves were controlled by an electronic circuit. Each wastewater applicator was fabricated from stainless steel pipe with holes punched along the lower edge to allow the wastewater to flow out. The wastewater entered the applicator at the center of the top edge. To overcome the problem of clogging, a water line with six solenoid valves was attached to the applicator and was used to flush out the applicator after feeding periods. The wastewater application system was fully automated and consisted of a motor driven pulley arrangement on each shelf to which the applicator tubes were attached. The motors (Sigma Model 20-3424SG-24007, Faber Industrial Technologies, Clifton, NJ) ran at $6 \mathrm{rpm}$ and were controlled by an electronic circuit. The system was set up so that each applicator traveled $122 \mathrm{~cm} \mathrm{(3}$ tray lengths). When a guide on an applicator hit a micro - switch located at each end of the shelf, the motor stopped. After a 3 second delay, the applicator traveled in the opposite direction. This process continued for the designated feeding time which was controlled by computer. Each compartment contained a sampling port located $2.0 \mathrm{~cm}$ from the bottom of the trough. Each sampling port was connected to a $2.7 \mathrm{~L}$ glass bottle using PVC tubing of $1.27 \mathrm{~cm}$ outside diameter and a valve.

A microcontroller (BASIC Stamp 2P24, Parallax, Inc., Rocklin, CA) was used to run the various components of the hydroponics system including the lighting, cooling, irrigation and supernatant collection units. Addressable latches were used to effectively increase the microcontroller's 24 input/output pins to the required number. The microcontroller was programmed using BASIC computer software (BASIC Stamp Windows Editor version 2.2.6, Parallax, Inc., Rocklin, CA). A real time clock (Dallas Semiconductor X1226, Maxim Integrated Products, Inc., Sunnyvale, CA) and a 1-Farad supercapacitor provided nonvolitile timing. A separate program (BASIC Stamp Windows Editor version 2.2.6, Parallax, Inc., Rocklin, CA) was used to set the real time clock.

\section{MATERIALS AND METHODS}

Experimental Materials: The water hyacinth, water lettuce and parrot's feather plants were purchased from Dubé Botanical Gardens, River John, Nova Scotia. The wastewater used in the study was obtained from an intensive, recirculating aquaculture facility stocked with Arctic charr (Salvelinus alpinus) located in Truro, Nova Scotia. The chemical analyses for the aquaculture wastewater are presented in Table 1.

Table 1: Chemical analysis of aquaculture wastewater

\begin{tabular}{lr}
\hline Parameter & \multicolumn{1}{c}{ Value } \\
\hline Total solids $\left(\mathrm{mg} \mathrm{L}^{-1}\right)$ & $826.67 \pm 28.87$ \\
Suspended solids $\left(\mathrm{mg} \mathrm{L}^{-1}\right)$ & $103.33 \pm 13.63$ \\
Total chemical oxygen demand $\left(\mathrm{mg} \mathrm{L}^{-1}\right)$ & $157.97 \pm 9.32$ \\
Soluble chemical oxygen demand $\left(\mathrm{mg} \mathrm{L}^{-1}\right)$ & $102.34 \pm 8.56$ \\
Ammonium-Nitrogen $\left(\mathrm{mg} \mathrm{L}^{-1}\right)$ & $2.08 \pm 0.50$ \\
Nitrite-Nitrogen $\left(\mathrm{mg} \mathrm{L}^{-1}\right)$ & $1.27 \pm 0.09$ \\
Nitrate-Nitrogen $\left(\mathrm{mg} \mathrm{L}^{-1}\right)$ & $21.64 \pm 0.60$ \\
Total phosphorus $\left(\mathrm{mg} \mathrm{L}^{-1}\right)$ & $6.30 \pm 0.00$ \\
Orthophosphate $\left(\mathrm{mg} \mathrm{L}^{-1}\right)$ & $4.49 \pm 0.18$ \\
Potassium $\left(\mathrm{mg} \mathrm{L}^{-1}\right)$ & $74.67 \pm 0.32$ \\
Calcium $\left(\mathrm{mg} \mathrm{L}^{-1}\right)$ & $59.90 \pm 0.95$ \\
Sodium $\left(\mathrm{mg} \mathrm{L}^{-1}\right)$ & $114.67 \pm 0.58$ \\
Sulfur $\left(\mathrm{mg} \mathrm{L}^{-1}\right)$ & $6.97 \pm 0.12$ \\
Chloride $\left(\mathrm{mg} \mathrm{L}^{-1}\right)$ & $86.67 \pm 0.58$ \\
Magnesium (mg L & $5.06 \pm 0.07$ \\
Manganese $\left(\mathrm{mg} \mathrm{L}^{-1}\right)$ & $0.20 \pm 0.00$ \\
Iron $\left(\mathrm{mg} \mathrm{L}^{-1}\right)$ & $0.03 \pm 0.01$ \\
Copper $\left(\mathrm{mg} \mathrm{L}^{-1}\right)$ & $0.06 \pm 0.00$ \\
Zinc $(\mathrm{mg} \mathrm{L}$ & $0.20 \pm 0.00$ \\
pH & $7.00 \pm 0.13$ \\
\hline
\end{tabular}


Experimental Procedure: The effects of retention time (6 and 12 days) on the growth and yield of three aquatic macrophytes (water hyacinth, water lettuce and parrot's feather) and the pollution potential reduction of the wastewater were investigated. The day length at a latitude of $45^{\circ} \mathrm{N}$ during the crop growing season (May $1^{\text {st }}$ to Sept $31^{\text {st }}$ ) is approximately 14 hours. Therefore, the lighting system was programmed to provide a daily photoperiod of 14 hours. The study was designed as a completely randomized $3 \times 2$ experiment with 2 replicates. This resulted in 12 treatments. Four compartments were utilized as controls and contained wastewater only.

On day 1 , with the valves controlling the sampling ports in the closed position, each compartment was filled with $12 \mathrm{~L}$ of aquaculture wastewater. Water hyacinth, water lettuce and parrot's feather were washed with tap water and weighed using an analytical balance (Model PM4600, Mettler Instrument Corporation, Hightstown, NJ). Each compartment was then stocked with the appropriate plant to provide approximately $50 \%$ plant coverage. This resulted in initial average masses for water hyacinth, water lettuce and parrot's feather of 204, 144 and $41 \mathrm{~g}$ tray $^{-1}$, respectively. The lighting system was activated and programmed to provide a daily photoperiod of 14 hours. The cooling system was programmed to operate with the lighting system. The aeration system was turned on and pressure regulators were adjusted to $0.340 \mathrm{~atm}$.

During the growth period (days 2 - 24), plant appearance was observed and recorded daily. The valves controlling the effluent tubes were opened and samples of effluent were collected from each compartment and refrigerated at $4{ }^{\circ} \mathrm{C}$ in labeled bottles until needed for chemical analyses. The required amounts of wastewater were applied to each compartment. Plants were removed from the compartments on day 24 and allowed to dry at room temperature $\left(22^{\circ} \mathrm{C}\right)$ for 24 hours. The biomass was measured using an analytical balance (Model PM4600, Mettler Instrument Corporation, Hightstown, NJ) and recorded.

Analyses: All effluent samples were analyzed for: total solids (TS), total chemical oxygen demand (COD), ammonium - nitrogen $\left(\mathrm{NH}_{4}{ }^{+}-\mathrm{N}\right)$, nitrite - nitrogen $\left(\mathrm{NO}_{2}{ }^{-} \mathrm{N}\right)$, nitrate - nitrogen $\left(\mathrm{NO}_{3}{ }^{-} \mathrm{N}\right)$, phosphate phosphorus $\left(\mathrm{PO}_{4}{ }^{3-}-\mathrm{P}\right)$ and $\mathrm{pH}$. The TS, COD, $\mathrm{NO}_{2}{ }^{-}-\mathrm{N}$ and $\mathrm{PO}_{4}{ }^{3-}-\mathrm{P}$ analyses were performed according to procedures described in Standard Methods for the Examination of Water and Wastewater ${ }^{[11]}$. The $\mathrm{NH}_{4}{ }^{+}-\mathrm{N}$ measurements were performed using the Kjeltec Auto Analyzer (Model 1030, Tecator, Höganäs, Sweden) according to the Kjeldahl method. The $\mathrm{NO}_{3}^{-}-\mathrm{N}$ analysis was performed according to the phenoldisulfonic acid technique described in Methods of Soil Analysis ${ }^{[12]}$. The $\mathrm{pH}$ of the wastewater was measured using a $\mathrm{pH}$ meter (Model 805MP, Fisher Scientific, Montreal, QC). The elemental composition $(\mathrm{Ca}, \mathrm{Cl}, \mathrm{Mg}, \mathrm{P}, \mathrm{K}, \mathrm{Na}, \mathrm{S}, \mathrm{B}$, $\mathrm{Cu}, \mathrm{Fe}, \mathrm{Mn}, \mathrm{Mo}, \mathrm{Se}$ and $\mathrm{Zn}$ ) of the wastewater was determined in the Minerals Engineering Center, Dalhousie University using flame atomic adsorption spectroscopy.

\section{RESULTS AND DISCUSSION}

Plant Growth: Initially, the plants in all compartments grew rapidly and appeared healthy with green color. The water hyacinth and water lettuce plants produced numerous daughter plants by vegetative propagation and parrot's feather grew rapidly across the water surface forming numerous branches at the nodes (Figure 3). By day 8 of the experiment, the surface area of compartments containing water hyacinth and water lettuce were completely covered, while compartments containing parrot's feather were approximately $60 \%$ covered.

At hydraulic retention times (HRTs) of 6 and 12 days, the average water hyacinth, water lettuce and parrot's feather yields were 83,51 and $51 \mathrm{~g}(\mathrm{dm}) \mathrm{m}^{-2}$ and 49,29 and $22 \mathrm{~g}(\mathrm{dm}) \mathrm{m}^{-2}$, giving average growth rates of $3.47,2.13$ and $2.11 \mathrm{~g}(\mathrm{dm}) \mathrm{m}^{-2}$ day $^{-1}$ and 2.05 ,

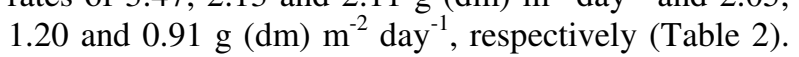
The effects of plant type and hydraulic retention time on plant yield were tested using a two-way analysis of variance (ANOVA) and a Duncan's multiple range test using SPSS (SPSS 14.0.1, SPSS Inc., Chicago, IL). The results are shown in Tables 3 and 4. The plant type had a significant effect on yield. The results showed that water hyacinth produced the highest yields followed by water lettuce and parrot's feather. The plant yield was also significantly affected by HRT and increased as the HRT was decreased due to the additional nutrients provided to the plants ${ }^{[9,13-14]}$.

Information in the literature about plant yields and growth rates are varying. Jo et al ${ }^{[8]}$ evaluated the growth of water hyacinth and water lettuce plants for 30 days on effluent from an intensive recirculating aquaculture system and reported biomass yields of 6402.5 and $10188 \mathrm{~g} \mathrm{~m}^{-2}$ for water hyacinth and water lettuce, respectively. Sooknah and Wilkie ${ }^{[9]}$ investigated the use of water hyacinth and water lettuce plants for reducing the nutrient content of an 


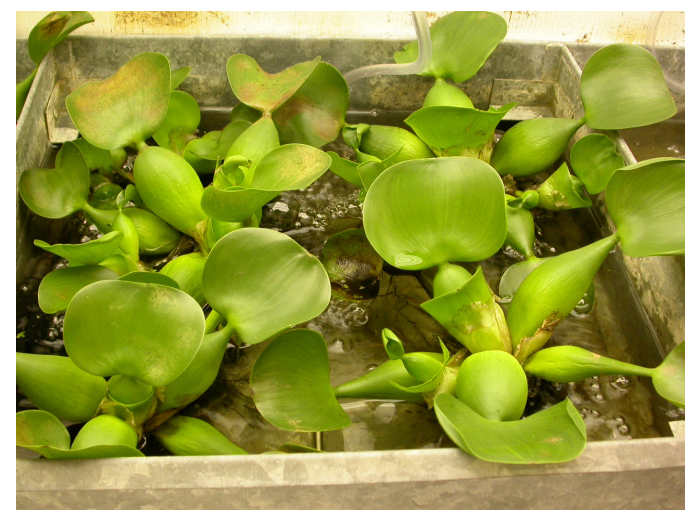

(a) water hyacinth

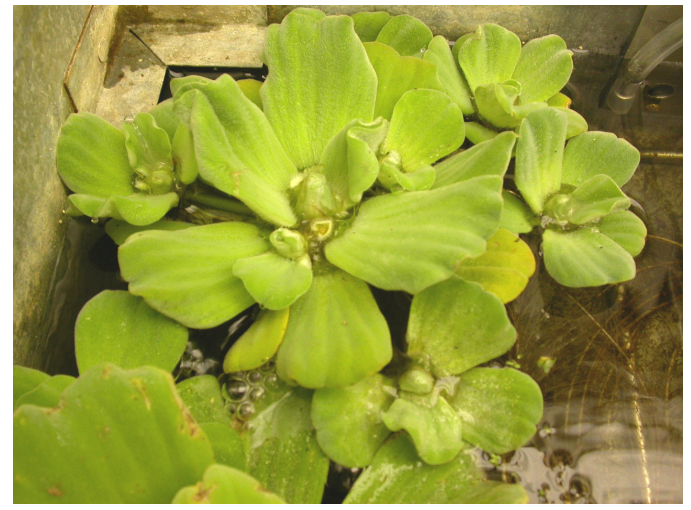

(b) water lettuce

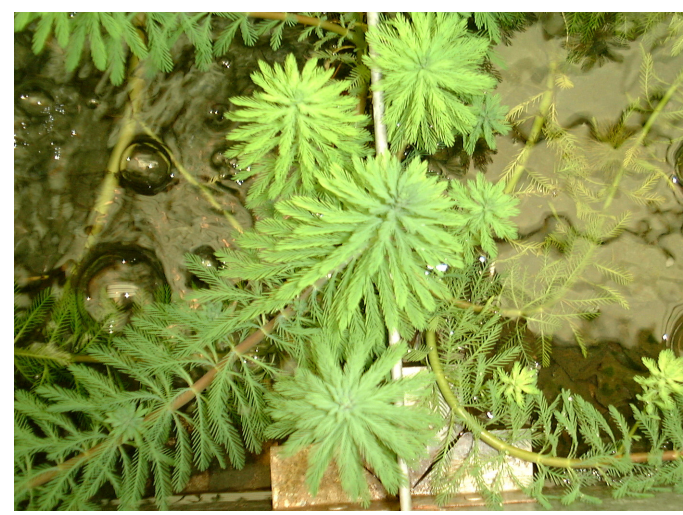

(c) parrot's feather

Fig. 3: The aquatic plants at day 14 of the experiment

anaerobically digested dairy manure. After 31 days of batch growth, the researchers reported biomass yields of 1608 and $30 \mathrm{~g}(\mathrm{dm}) \mathrm{m}^{-2}$ for water hyacinth and water lettuce, respectively. DeBusk et al. ${ }^{[14]}$ evaluated the use of a water hyacinth based treatment system for nutrient removal from a secondarily treated municipal wastewater and reported an average plant productivity of $16 \mathrm{~g}(\mathrm{dm}) \mathrm{m}^{-2} \mathrm{day}^{-1}$. Wen and Recknagel ${ }^{[16]}$ examined the use of parrot's feather for treatment of agricultural drainage waters and reported an average growth rate for parrot's feather of $7.12 \mathrm{~g}(\mathrm{dm}) \mathrm{m}^{-2} \mathrm{day}^{-1}$.

Table 2: Average plant yields and growth rates after 24 days of growth in aquaculture wastewater

\begin{tabular}{lccc}
\hline Plant & $\begin{array}{l}\text { HRT } \\
(\text { days })\end{array}$ & $\begin{array}{l}\text { Yield } \\
\left(\mathrm{g} \mathrm{m}^{-2}\right)\end{array}$ & $\begin{array}{l}\text { Growth rate } \\
\left(\mathrm{g} / \mathrm{m}^{-2} / \mathrm{day}^{-1}\right)\end{array}$ \\
\hline Water hyacinth & 6 & $83 \pm 8.4$ & $3.47 \pm 0.35$ \\
& 12 & $49 \pm 2.6$ & $2.05 \pm 0.11$ \\
Water lettuce & 6 & $51 \pm 1.3$ & $2.13 \pm 0.05$ \\
& 12 & $29 \pm 4.1$ & $1.20 \pm 0.46$ \\
Parrot's feather & 6 & $51 \pm 1.5$ & $2.11 \pm 0.06$ \\
& 12 & $22 \pm 3.4$ & $0.91 \pm 0.14$ \\
\hline
\end{tabular}

Table 3: Results of a two-way ANOVA for plant yields as affected by plant type and hydraulic retention time

\begin{tabular}{lrrrrr}
\hline Source & DF & \multicolumn{1}{c}{ SS } & MS & \multicolumn{1}{c}{ F } & P \\
\hline Total & 11 & 4848.48 & & & \\
Model & 5 & 4635.76 & & & \\
$\quad$ Plant type & 2 & 2133.99 & 1067.00 & 30.10 & 0.001 \\
HRT & 1 & 2431.86 & 2431.86 & 68.59 & 0.000 \\
$\quad$ Plant type $\times$ HRT & 2 & 69.91 & 34.95 & 0.99 & 0.426 \\
$\quad$ Error & 6 & 212.72 & 35.45 & & \\
\hline
\end{tabular}

Differences are considered significant at the $\mathrm{p} \leq 0.05$ level $(95 \%$ confidence interval)

Table 4: Results of a Duncan's multiple range test for plant yields as affected by plant type and hydraulic retention time

\begin{tabular}{lll}
\hline Parameter & $\begin{array}{c}\text { Average yields } \\
\left(\mathrm{g} \mathrm{dm} \mathrm{m}^{-2}\right)\end{array}$ & $\begin{array}{c}\text { Duncan subsets } \\
(\alpha=0.05)\end{array}$ \\
\hline Plant type & & \\
$\quad$ Water hyacinth & 66.25 & $\mathrm{~A}$ \\
$\quad$ Water lettuce & 40.00 & $\mathrm{~B}$ \\
$\quad$ Parrots feather & 36.29 & $\mathrm{~B}$ \\
HRT (days) & & \\
6 & 61.75 & $\mathrm{~A}$ \\
12 & 33.28 & $\mathrm{~B}$ \\
\hline
\end{tabular}

Treatments with different numbers are significantly different at the $\mathrm{p}$ $\leq 0.05$ level

Effluent Quality: Table 5 shows the influent and effluent total solids (TS), chemical oxygen demand (COD), ammonium - nitrogen $\left(\mathrm{NH}_{4}{ }^{+}-\mathrm{N}\right)$, nitrite nitrogen $\left(\mathrm{NO}_{2}{ }^{-} \mathrm{N}\right)$, nitrate - nitrogen $\left(\mathrm{NO}_{3}{ }^{-} \mathrm{N}\right)$ and phosphate - phosphorus $\left(\mathrm{PO}_{4}-\mathrm{P}\right)$ concentrations and the removal efficiencies for each water quality parameter. The effects of plant type and hydraulic retention time on the reductions of these parameters were tested using a two-way analysis of variance (ANOVA) and a Duncan's multiple range test using SPSS (SPSS 14.0.1, SPSS Inc., Chicago, IL).

Total solids: The average total solids (TS) concentration in the aquaculture wastewater was $827 \pm$ $28 \mathrm{mg} \mathrm{L}^{-1}$. Feces, uneaten feed and bacterial biomass 
Am. J. Applied Sci., 5 (4): 440-453, 2008

Table 5: Water quality parameters

\begin{tabular}{|c|c|c|c|c|c|c|}
\hline \multirow[b]{2}{*}{ Parameter } & \multirow[b]{2}{*}{ HRT (days) } & \multirow[b]{2}{*}{ Treatment } & \multirow[b]{2}{*}{$\begin{array}{l}\text { Influent } \\
\left(\mathrm{mg} \mathrm{L}^{-1}\right)^{\mathrm{a}}\end{array}$} & \multirow[b]{2}{*}{$\begin{array}{l}\text { Effluent } \\
\left(\mathrm{mg} \mathrm{L}^{-1}\right)^{\mathrm{b}}\end{array}$} & \multicolumn{2}{|c|}{ Reduction } \\
\hline & & & & & $\left(\mathrm{mg} \mathrm{L}^{-1}\right)$ & $(\%)$ \\
\hline \multirow[t]{8}{*}{ TS } & 6 & Control & $827.00 \pm 29.0$ & $650.00 \pm 28$ & 177.00 & 21.4 \\
\hline & & Water hyacinth & $827.00 \pm 29.0$ & $500.00 \pm 26$ & 327.00 & 39.5 \\
\hline & & Water lettuce & $827.00 \pm 29.0$ & $585.00 \pm 13$ & 242.00 & 29.3 \\
\hline & & Parrots feather & $827.00 \pm 29.0$ & $650.00 \pm 18$ & 177.00 & 21.4 \\
\hline & 12 & Control & $827.00 \pm 29.0$ & $600.00 \pm 12$ & 227.00 & 27.4 \\
\hline & & Water hyacinth & $827.00 \pm 29.0$ & $430.00 \pm 21$ & 397.00 & 48.0 \\
\hline & & Water lettuce & $827.00 \pm 29.0$ & $450.00 \pm 16$ & 377.00 & 45.6 \\
\hline & & Parrots feather & $827.00 \pm 29.0$ & $525.00 \pm 21$ & 302.00 & 36.5 \\
\hline \multirow[t]{8}{*}{ COD } & 6 & Control & $158.00 \pm 09.3$ & $34.70 \pm 0.6$ & 123.30 & 78.1 \\
\hline & & Water hyacinth & $158.00 \pm 09.3$ & $16.60 \pm 1.0$ & 141.40 & 89.5 \\
\hline & & Water lettuce & $158.00 \pm 09.3$ & $27.70 \pm 1.6$ & 130.30 & 82.5 \\
\hline & & Parrots feather & $158.00 \pm 09.3$ & $24.70 \pm 1.0$ & 133.30 & 84.4 \\
\hline & 12 & Control & $158.00 \pm 09.3$ & $45.70 \pm 1.2$ & 112.30 & 71.1 \\
\hline & & Water hyacinth & $158.00 \pm 09.3$ & $24.70 \pm 3.0$ & 133.30 & 84.4 \\
\hline & & Water lettuce & $158.00 \pm 09.3$ & $27.70 \pm 2.4$ & 130.30 & 82.5 \\
\hline & & Parrots feather & $158.00 \pm 09.3$ & $33.70 \pm 1.9$ & 124.30 & 78.7 \\
\hline \multirow[t]{8}{*}{$\mathrm{NH}_{4}{ }^{+}-\mathrm{N}$} & 6 & Control & $2.08 \pm 0.50$ & $1.38 \pm 0.11$ & 0.70 & 33.8 \\
\hline & & Water hyacinth & $2.08 \pm 0.50$ & $0.54 \pm 0.06$ & 1.58 & 76.0 \\
\hline & & Water lettuce & $2.08 \pm 0.50$ & $0.67 \pm 0.21$ & 1.41 & 68.0 \\
\hline & & Parrots feather & $2.08 \pm 0.50$ & $0.75 \pm 0.25$ & 1.33 & 64.0 \\
\hline & 12 & Control & $2.08 \pm 0.50$ & $1.43 \pm 0.10$ & 0.66 & 31.9 \\
\hline & & Water hyacinth & $2.08 \pm 0.50$ & 0.50 & 1.58 & 76.0 \\
\hline & & Water lettuce & $2.08 \pm 0.50$ & $0.58 \pm 0.11$ & 1.47 & 72.0 \\
\hline & & Parrots feather & $2.08 \pm 0.50$ & $0.92 \pm 0.14$ & 1.16 & 55.9 \\
\hline \multirow[t]{8}{*}{$\mathrm{NO}_{2}^{-}-\mathrm{N}$} & 6 & Control & $1.27 \pm 0.09$ & $0.84 \pm 0.05$ & 0.43 & 33.9 \\
\hline & & Water hyacinth & $1.27 \pm 0.09$ & $0.30 \pm 0.07$ & 0.97 & 76.4 \\
\hline & & Water lettuce & $1.27 \pm 0.09$ & $0.44 \pm 0.04$ & 0.83 & 65.0 \\
\hline & & Parrots feather & $1.27 \pm 0.09$ & $0.64 \pm 0.10$ & 0.63 & 49.6 \\
\hline & 12 & Control & $1.27 \pm 0.09$ & $0.60 \pm 0.10$ & 0.67 & 52.7 \\
\hline & & Water hyacinth & $1.27 \pm 0.09$ & $0.12 \pm 0.08$ & 1.15 & 90.6 \\
\hline & & Water lettuce & $1.27 \pm 0.09$ & $0.32 \pm 0.09$ & 0.95 & 74.5 \\
\hline & & Parrots feather & $1.27 \pm 0.09$ & $0.49 \pm 0.07$ & 0.78 & 61.4 \\
\hline \multirow[t]{8}{*}{$\mathrm{NO}_{3}-\mathrm{N}$} & 6 & Control & $21.64 \pm 0.60$ & $16.11 \pm 0.40$ & 5.53 & 25.6 \\
\hline & & Water hyacinth & $21.64 \pm 0.60$ & $12.18 \pm 0.20$ & 9.46 & 43.7 \\
\hline & & Water lettuce & $21.64 \pm 0.60$ & $12.60 \pm 0.20$ & 9.04 & 41.8 \\
\hline & & Parrots feather & $21.64 \pm 0.60$ & $14.17 \pm 0.80$ & 7.47 & 34.5 \\
\hline & 12 & Control & $21.64 \pm 0.60$ & $16.22 \pm 0.20$ & 5.42 & 25.0 \\
\hline & & Water hyacinth & $21.64 \pm 0.60$ & $9.87 \pm 0.20$ & 11.77 & 54.4 \\
\hline & & Water lettuce & $21.64 \pm 0.60$ & $10.19 \pm 0.30$ & 11.45 & 52.9 \\
\hline & & Parrots feather & $21.64 \pm 0.60$ & $10.62 \pm 0.30$ & 11.02 & 50.9 \\
\hline \multirow[t]{8}{*}{$\mathrm{PO}_{4}-\mathrm{P}$} & 6 & Control & $4.49 \pm 0.18$ & $2.77 \pm 0.25$ & 1.72 & 38.4 \\
\hline & & Water hyacinth & $4.49 \pm 0.18$ & $1.52 \pm 0.14$ & 2.97 & 66.2 \\
\hline & & Water lettuce & $4.49 \pm 0.18$ & $1.57 \pm 0.14$ & 2.92 & 65.0 \\
\hline & & Parrots feather & $4.49 \pm 0.18$ & $1.59 \pm 0.01$ & 2.90 & 64.5 \\
\hline & 12 & Control & $4.49 \pm 0.18$ & $2.55 \pm 0.06$ & 1.94 & 43.3 \\
\hline & & Water hyacinth & $4.49 \pm 0.18$ & $1.04 \pm 0.18$ & 3.45 & 76.8 \\
\hline & & Water lettuce & $4.49 \pm 0.18$ & $1.11 \pm 0.28$ & 3.38 & 75.3 \\
\hline & & Parrots feather & $4.49 \pm 0.18$ & $1.49 \pm 0.12$ & 3.00 & 66.8 \\
\hline
\end{tabular}

${ }^{\mathrm{a}}$ day $1 ;{ }^{\mathrm{b}}$ day 24

are the main sources of TS in aquaculture effluent ${ }^{[17-19]}$. At HRTs of 6 and 12 days, the average TS reductions from the controls and the compartments containing water hyacinth, water lettuce and parrot's feather were $21.4,39.5,29.3$ and $21.4 \%$ and $27.4,48.0,45.6$ and $36.5 \%$, respectively. The results of the statistical analyses are presented in Tables 6 and 7. Both the plant type and HRT had significant effects on TS reductions. The TS reductions were higher in the compartments containing water hyacinth followed by the compartments containing water lettuce and parrot's feather. Parrot's feather did not seem to have any effect on the TS reduction as compared to the control. The TS reductions increased with the longer retention time. 
Am. J. Applied Sci., 5 (4): 440-453, 2008

Table 6: Results of a two-way ANOVA for TS reductions as affected by plant type and hydraulic retention time

\begin{tabular}{lrrrrr}
\hline Source & DF & \multicolumn{1}{c}{ SS } & MS & \multicolumn{1}{c}{ F } & P \\
\hline Total & 23 & 2414.67 & & & \\
Model & 7 & 2228.52 & & & \\
$\quad$ Plant type & 3 & 1338.78 & 446.260 & 38.36 & 0.000 \\
HRT & 1 & 780.90 & 780.900 & 67.12 & 0.000 \\
Plant type $\times$ HRT & 3 & 108.84 & 36.282 & 3.12 & 0.055 \\
$\quad$ Error & 16 & 186.14 & 11.634 & & \\
\hline D
\end{tabular}

Differences are considered significant at the $\mathrm{p} \leq 0.05$ level $(95 \%$ confidence interval)

Table 7: Results of a Duncan's multiple range test for TS reductions as affected by plant type and hydraulic retention time

\begin{tabular}{lcc}
\hline Parameter & $\begin{array}{c}\text { Average TS reduction } \\
(\%)\end{array}$ & $\begin{array}{c}\text { Duncan subsets } \\
(\alpha \leq 0.05)\end{array}$ \\
\hline Plant type & & \\
$\quad$ Control & 24.42 & $\mathrm{~A}$ \\
$\quad$ Water hyacinth & 43.77 & $\mathrm{~B}$ \\
$\quad$ Water lettuce & 37.32 & $\mathrm{C}$ \\
$\quad$ Parrots feather & 28.95 & $\mathrm{~A}$ \\
HRT (days) & & \\
6 & 27.91 & $\mathrm{~A}$ \\
12 & 39.32 & $\mathrm{~B}$ \\
\hline
\end{tabular}

Treatments with different numbers are significantly different at the $\mathrm{p} \leq 0.05$ level

Sooknah and Wilkie ${ }^{[9]}$ compared the potential of water hyacinth and water lettuce plants for reducing the nutrient content of an anaerobically digested dairy manure and reported suspended solids reductions of 56.7, 92.0 and $80.6 \%$ after 31 days of batch growth in the control and in the compartments containing water hyacinth and water lettuce, respectively. Nuttall ${ }^{[20]}$ examined the ability of parrot's feather for nutrient reduction from a secondarily treated municipal wastewater over a 13 month period and reported suspended solids removal efficiencies ranging from 12.8 to $65.0 \%$. John ${ }^{[21]}$ investigated the use of water hyacinth for TS removal from rubber factory and palm oil mill effluents and reported TS reductions of 16.9, 39.4 and $57.0 \%$ at hydraulic retention times (HRTs) of 5,10 and 15 days when water hyacinths were grown on undiluted raw rubber factory effluent and 32.4, 42.9, and $44.7 \%$ at HRTs of 10,20 and 25 days when water hyacinths were grown on an anaerobically treated palm oil mill effluent, respectively.

Levels of TS in aquaculture wastewaters must be limited for several reasons. Effluents containing high concentrations of suspended solids may form a plume of discolored water in the discharge area reducing light penetration, phytoplankton productivity and feed uptake by visual feeders ${ }^{[22]}$. Excessive sedimentation can abrade or cover respiratory surfaces (gills) of aquatic organisms, offer a suitable habitat for the proliferation of pathogenic organisms, smother eggs and larvae and bury and smother communities of benthic organisms reducing the biodiversity of the ecosystem ${ }^{[18,}{ }^{19]}$. According to Lawson ${ }^{[3]}$ and Meade ${ }^{[23]}$, waters used for the culture of aquatic organisms should contain less than $480 \mathrm{mg} \mathrm{L}^{-1}$ total solids (80 and $400 \mathrm{mg} \mathrm{L}^{-1}$ of total suspended and total dissolved solids, respectively). Only the compartments containing water hyacinth and water lettuce at a hydraulic retention time of 12 days produced effluents suitable for reuse in aquaculture.

Chemical Oxygen Demand: The aquaculture wastewater had an average chemical oxygen demand (COD) concentration of $158 \pm 9.32 \mathrm{mg} \mathrm{L}^{-1}$. Uneaten or regurgitated food and fecal production are the major sources of organic matter in aquaculture effluents ${ }^{[22,24]}$. Both the plant type and the HRT had significant effects on the COD reduction. The COD removal was higher in the compartments containing water hyacinth followed by the compartments containing water lettuce and parrot's feather. At HRTs of 6 and 12 days, the average COD reductions from the controls and the compartments containing water hyacinth, water lettuce and parrot's feather were $78.1,89.5,82.5$ and $84.4 \%$ and $71.1,84.4,82.5$ and $78.7 \%$, respectively. The COD reductions decreased as hydraulic retention time was increased. The results of the statistical analysis are presented in Tables 8 and 9.

Table 8: Results of a two-way ANOVA for COD reductions as affected by plant type and hydraulic retention time

\begin{tabular}{lrrrrl}
\hline Source & DF & \multicolumn{1}{l}{ SS } & \multicolumn{1}{c}{ MS } & \multicolumn{1}{c}{ F } & \multicolumn{1}{l}{ P } \\
\hline Total & 23 & 681.513 & & & \\
Model & 7 & 629.507 & & & \\
$\quad$ Plant type & 3 & 469.463 & 156.488 & 48.14 & 0.000 \\
HRT & 1 & 117.927 & 117.927 & 36.28 & 0.000 \\
Plant type $\times$ HRT & 3 & 42.117 & 14.039 & 4.32 & 0.021 \\
$\quad$ Error & 16 & 52.007 & 3.250 & & \\
\hline
\end{tabular}

Differences are considered significant at the $\mathrm{p} \leq 0.05$ level $(95 \%$ confidence interval)

Table 9: Results of a Duncan's multiple range test for COD reductions as affected by plant type and hydraulic retention time

\begin{tabular}{lcc}
\hline Parameter & $\begin{array}{c}\text { Average COD reduction } \\
(\%)\end{array}$ & $\begin{array}{c}\text { Duncan subsets } \\
(\alpha=0.05)\end{array}$ \\
\hline Plant type & & \\
Control & 74.58 & $\mathrm{~A}$ \\
Water hyacinth & 86.93 & $\mathrm{~B}$ \\
Water lettuce & 82.47 & $\mathrm{C}$ \\
$\quad$ Parrots feather & 81.55 & $\mathrm{C}$ \\
HRT (days) & & \\
6 & 83.60 & $\mathrm{~A}$ \\
12 & 79.17 & $\mathrm{~B}$ \\
\hline
\end{tabular}

Treatments with different numbers are significantly different at the $\mathrm{p}$ $\mathrm{p} \leq 0.05$ level 
Sooknah and Wilkie ${ }^{[9]}$ investigated the use of water hyacinth and water lettuce plants for reducing the nutrient content of an anaerobically digested dairy manure and reported COD reductions of $65.8,80.5$ and $79.6 \%$ in the control and in the compartments containing water hyacinth and water lettuce after 31 days. Awuah et al. ${ }^{[25]}$ evaluated the potential use of water lettuce for pollutant removal from a low strength, anaerobically treated domestic sewage and reported COD reductions of 59\% after 6 months of operation. Jing et al. ${ }^{[26]}$ investigated the use of water lettuce for nutrient removal from an artificially prepared wastewater over a 30 day period and reported average COD reductions in the controls and in the compartments containing water lettuce of $72.1,70.8$, 86.2 and $94.7 \%$ and $83.3,75.0,87.5$ and $87.2 \%$ at hydraulic retention times of $1,2,3$ and 4 days, respectively. John ${ }^{[21]}$ investigated the use of water hyacinth for nutrient removal from rubber factory and palm oil mill effluents and reported COD reductions of 69.0, 80.2 and $88.7 \%$ at hydraulic retention times of 5, 10 and 15 days when water hyacinths were grown on undiluted raw rubber factory effluent. When water hyacinths were grown on an anaerobically treated palm oil mill effluent, COD reductions of 76.7, 83.1 and 87.3\% were observed at HRTs of 10, 20 and 25 days, respectively.

The oxygen demanding materials in waters used for the culture of fish and shellfish must be limited for several reasons. Waters rich in organic matter will lead to an increase in oxygen consumption by heterotrophic microorganisms in the water column. Oxygen depletion, formation of anaerobic bacterial mats and production of ammonia, hydrogen sulfide and methane gases are problems which may arise when oxygen demand exceeds its supply. These gases are highly toxic to aquatic organisms ${ }^{[27-30]}$. Limits for COD concentrations in waters used for the culture of aquatic organisms have not been defined.

Ammonium - Nitrogen: The aquaculture wastewater contained $2.08 \pm 0.5 \mathrm{mg} \mathrm{L}^{-1}$ ammonium - nitrogen $\left(\mathrm{NH}_{4}{ }^{+}-\mathrm{N}\right)$. In fish and shellfish, ammonia is the major nitrogenous waste product of protein catabolism, and it is excreted primarily in un-ionized form $\left(\mathrm{NH}_{3}\right)$ through the gills ${ }^{[31,32]}$. Ammonium is also produced through the microbial decomposition of fish feces and uneaten food in a process called ammonification.

Organic $-\mathrm{N} \rightarrow \mathrm{NH}_{4}^{+}$

Ammonification refers to a series of biological transformations that convert organically bound nitrogen to ammonium - nitrogen under both aerobic and anaerobic conditions. The reactions involved in the decomposition release energy which can then be utilized by the microorganisms for growth and reproduction or to sustain metabolic functions ${ }^{[33]}$. Heterotrophic microorganisms responsible for ammonification belong to the genera Pseudomonas, Vibrio, Proteus, Serratia, Bacillus and Clostridium.

The results of the statistical analyses are shown in Tables 10 and 11. The $\mathrm{NH}_{4}{ }^{+}-\mathrm{N}$ reductions were significantly affected by plant type, but were not significantly influenced by hydraulic retention time. At HRTs of 6 and 12 days, the average $\mathrm{NH}_{4}{ }^{+} \mathrm{N}$ reductions from the controls and the compartments containing water hyacinth, water lettuce and parrot's feather were $31.8,76.0,68.0$ and $64.0 \%$ and $31.9,76.0,72.0$, and $55.9 \%$, respectively.

Table 10: Results of a two-way ANOVA for $\mathrm{NH}_{4}{ }^{+}-\mathrm{N}$ reductions as affected by plant type and hydraulic retention time

\begin{tabular}{lrrrrr}
\hline Source & DF & \multicolumn{1}{c}{ SS } & \multicolumn{1}{c}{ MS } & \multicolumn{1}{c}{ F } & P \\
\hline Total & 23 & 7992.48 & & & \\
Model & 7 & 7002.39 & & & \\
$\quad$ Plant type & 3 & 6881.18 & 2293.73 & 37.07 & 0.000 \\
HRT & 1 & 5.70 & 5.70 & 0.09 & 0.765 \\
$\quad$ Plant type $\times$ HRT & 3 & 115.51 & 38.50 & 0.62 & 0.611 \\
$\quad$ Error & 16 & 990.08 & 61.88 & & \\
\hline
\end{tabular}

Differences are considered significant at the p 0.05 level $(95 \%$ confidence interval)

Table 11: Results of a Duncan's multiple range test for $\mathrm{NH}_{4}{ }^{+}-\mathrm{N}$ reductions as affected by plant type and hydraulic retention time

\begin{tabular}{lcc}
\hline Parameter & $\begin{array}{c}\text { Average } \mathrm{NH}_{4}{ }^{+}-\mathrm{N} \text { reduction } \\
(\%)\end{array}$ & $\begin{array}{c}\text { Duncan subsets } \\
(\alpha=0.05)\end{array}$ \\
\hline Plant type & 31.85 & $\mathrm{~A}$ \\
Control & 76.00 & $\mathrm{~B}$ \\
Water hyacinth & 69.98 & $\mathrm{~B}, \mathrm{C}$ \\
Water lettuce & 59.95 & $\mathrm{C}, \mathrm{D}$ \\
Parrots feather & & \\
HRT (days) & 59.93 & $\mathrm{~A}$ \\
6 & 58.96 & $\mathrm{~A}$ \\
12 & & \\
\hline
\end{tabular}

Treatments with different numbers are significantly different at the $\mathrm{p}$ $\leq 0.05$ level

Jo et al. ${ }^{[8]}$ evaluated the potential of water hyacinth and water lettuce plants for removal of $\mathrm{NH}_{4}{ }^{+}-\mathrm{N}$ from an intensive, recirculating aquaculture system effluent and reported that at water temperatures of $30-38.5^{\circ} \mathrm{C}$ the water lettuce and water hyacinth plants reduced the concentrations of $\mathrm{NH}_{4}{ }^{+} \mathrm{N}$ in the wastewater from 2.3 to $0.4 \mathrm{mg} \mathrm{L}^{-1}$ and $0.6 \mathrm{mg} \mathrm{L}^{-1}$ over a 48 hour period. DeBusk et al. ${ }^{[15]}$ evaluated the use of a water hyacinth based treatment system for nutrient removal from a secondarily treated municipal wastewater over a three month period and found that the $\mathrm{NH}_{4}{ }^{+}-\mathrm{N}$ concentration 
in the wastewater was reduced from 2.57 to 0.03 $\mathrm{mg} \mathrm{L}^{-1}$. Dedes and O'Shaughnessy ${ }^{[14]}$ investigated the use of duckweed (Lemna minor) for treatment of domestic wastewater over 74 days under 5 different hydraulic retention times $(2.0,2.7,5.5,5.6$ and 11.7 days) and reported that the fraction of $\mathrm{NH}_{4}{ }^{+}-\mathrm{N}$ removed remained relatively constant at approximately $54-58 \%$ despite changes in hydraulic retention time.

Accumulation of ammonia in water is one of the major causes of functional and structural disorders in aquatic organisms ${ }^{[34,35]}$. Only unionized ammonia is toxic to fish because it can readily diffuse across the gill membranes into the circulation, whereas the ionized form $\left(\mathrm{NH}_{4}{ }^{+}\right)$cannot ${ }^{[32,35]}$. The $\mathrm{NH}_{3}-\mathrm{N}$ concentrations in the final effluents from the aquatic plants experiment were $0.05,0.04$ and $0.04 \mathrm{mg} \mathrm{L}^{-1}$ and $0.06,0.04$ and 0.07 $\mathrm{mg} \mathrm{L}^{-1}$ in compartments containing water hyacinth, water lettuce and parrot's feather at HRTs of 6 and 12 days, respectively. Lawson ${ }^{[3]}$ and Meade ${ }^{[23]}$ recommend that ammonia concentrations do not exceed $0.02 \mathrm{mg} \mathrm{L}^{-1}$ in water used for culture of aquatic animals. The aquatic plants did not produce effluents suitable for reuse in aquaculture under the wastewater application rates studied.

Nitrite - Nitrogen: The aquaculture wastewater had an average nitrite - nitrogen $\left(\mathrm{NO}_{2}^{-}-\mathrm{N}\right)$ concentration of $1.27 \pm 0.09 \mathrm{mg} \mathrm{L}^{-1}$. In natural waters, ammonium is converted rather rapidly to nitrite $\left(\mathrm{NO}_{2}{ }^{-}\right)$and further to nitrate $\left(\mathrm{NO}_{3}{ }^{-}\right)$by aerobic bacteria from the genera Nitrosomonas and Nitrobacter, through a two-step process called nitrification $^{[36,37]}$.

$$
\begin{aligned}
& 2 \mathrm{NH}_{3}+3 \mathrm{O}_{2} \stackrel{\text { Nitrosomonas }}{\longrightarrow} 2 \mathrm{NO}_{2}^{-}+2 \mathrm{H}^{+}+2 \mathrm{H}_{2} \mathrm{O} \\
& 2 \mathrm{NO}_{2}^{-}+\mathrm{O}_{2} \stackrel{\text { Nitrobacter }}{\longrightarrow} 2 \mathrm{NO}_{3}^{-}
\end{aligned}
$$

Nitrification was facilitated by the continuous aeration of the system compartments during the experiments. Princic et al. ${ }^{[38]}$ reported that the optimum $\mathrm{pH}$ range for conversion of $\mathrm{NH}_{4}^{+}$to nitrite $\left(\mathrm{NO}_{2}^{-}\right)$is between 5.8 and 8.5. The $\mathrm{pH}$ of the water in all experiments was within this range.

At hydraulic retention times of 6 and 12 days, the average $\mathrm{NO}_{2}^{-}-\mathrm{N}$ reductions from the controls and the compartments containing water hyacinth, water lettuce and parrot's feather were 33.9, 76.4, 65.0 and $49.6 \%$ and 52.7, 90.6, 74.5 and $61.4 \%$, respectively. The results of the statistical analyses are presented in Tables 12 and 13. Both the plant type and the HRT had significant effects on $\mathrm{NO}_{2}^{-}-\mathrm{N}$ reductions. The $\mathrm{NO}_{2}^{-}-\mathrm{N}$ removal was higher in the compartments containing water hyacinth followed by the compartments containing water lettuce and parrot's feather, although the difference between parrot's feather and water lettuce was not significant. The $\mathrm{NO}_{2}{ }^{-} \mathrm{N}$ reductions increased with the longer retention time.

Table 12: Results of a two-way ANOVA for $\mathrm{NO}_{2}{ }^{-}-\mathrm{N}$ reductions as affected by plant type and hydraulic retention time

\begin{tabular}{lrrrrr}
\hline Source & DF & \multicolumn{1}{c}{ SS } & MS & F & P \\
\hline Total & 23 & 7288.52 & & & \\
Model & 7 & 6677.38 & & & \\
$\quad$ Plant type & 3 & 4001.41 & 1333.80 & 34.92 & 0.000 \\
HRT & 1 & 1030.97 & 1030.97 & 26.99 & 0.000 \\
Plant type $\times$ HRT & 3 & 1645.00 & 548.33 & 14.36 & 0.000 \\
Error & 16 & 0611.13 & 038.20 & & \\
\hline
\end{tabular}

Differences are considered significant at the $\mathrm{p} \leq 0.05$ level $(95 \%$ confidence interval)

Table 13: Results of a Duncan's multiple range test for $\mathrm{NO}_{2}{ }^{-} \mathrm{N}$ reductions as affected by plant type and hydraulic retention time

\begin{tabular}{lll}
\hline Parameter & $\begin{array}{c}\text { Average } \mathrm{NO}_{2}-\mathrm{N} \text { reduction } \\
(\%)\end{array}$ & $\begin{array}{c}\text { Duncan subsets } \\
(\alpha=0.05)\end{array}$ \\
\hline Plant type & & \\
$\quad$ Control & 47.63 & $\mathrm{~A}$ \\
Water hyacinth & 83.50 & $\mathrm{~B}$ \\
$\quad$ Water lettuce & 59.85 & $\mathrm{C}$ \\
$\quad$ Parrots feather & 62.07 & $\mathrm{C}$ \\
HRT (days) & & \\
6 & 56.71 & $\mathrm{~A}$ \\
12 & 69.82 & $\mathrm{~B}$ \\
\hline
\end{tabular}

Treatments with different numbers are significantly different at the $\mathrm{p}$ $\leq 0.05$ level

Jo et al. ${ }^{[8]}$ evaluated the potential of water hyacinth and water lettuce plants for removal of $\mathrm{NO}_{2}^{-}-\mathrm{N}$ from an intensive, recirculating aquaculture system effluent over a 48 hour period and found that the $\mathrm{NO}_{2}{ }^{-} \mathrm{N}$ concentration in the wastewater was reduced from 0.197 to 0.024 and $0.029 \mathrm{mg} \mathrm{L}^{-1}$ in aquaria containing water lettuce and water hyacinth, respectively. DeBusk et al. ${ }^{[15]}$ evaluated the use of a water hyacinth based treatment system for nutrient removal from a secondarily treated municipal wastewater over a three month period and found that the $\mathrm{NO}_{2}^{-}-\mathrm{N}$ concentration in the wastewater was reduced from 1.32 to $0.08 \mathrm{mg} \mathrm{L}$ 1

Although $\mathrm{NO}_{2}^{-}-\mathrm{N}$ is considerably less toxic than $\mathrm{NH}_{3}-\mathrm{N}$, it may be more important than ammonia toxicity in intensive, recirculating aquaculture systems because it tends to accumulate in the recirculated water as a result of incomplete bacterial oxidation ${ }^{[8,36]}$. Nitrite toxicity is associated with its ability to diffuse across the gills and into the blood circulation. When nitrite is absorbed by aquatic animals, the iron (or copper) in haemoglobin (haemocyanin) is oxidized from the ferrous (or cuprous) to the ferric (or cupric) state. The 
Am. J. Applied Sci., 5 (4): 440-453, 2008

resulting product is called methaemoglobin (methaemocyanin) and it is unable to bind and transport oxygen $^{[3,39-40]}$.

$4 \mathrm{Hb}\left(\mathrm{Fe}^{2+}\right) \mathrm{O}_{2}+4 \mathrm{NO}_{2}{ }^{-}+4 \mathrm{H}^{+} \rightarrow 4 \mathrm{Hb}\left(\mathrm{Fe}^{3+}\right)+4 \mathrm{NO}_{3}{ }^{-}+\mathrm{O}_{2}+2 \mathrm{H}_{2} \mathrm{O}$

The average $\mathrm{NO}_{2}^{-}-\mathrm{N}$ concentrations in the final effluent from the hydroponics system ranged from 0.30 to $0.64 \mathrm{mg} \mathrm{L}^{-1}$ and from 0.12 to $0.49 \mathrm{mg} \mathrm{L}^{-1}$ at HRTs of 6 and 12 days, respectively. Poxton ${ }^{[31]}$ recommends a $\mathrm{NO}_{2}^{-}-\mathrm{N}$ concentration less than $0.02 \mathrm{mg} \mathrm{L}^{-1}$ in water used for the culture of most freshwater fish.

Nitrate - Nitrogen: The aquaculture wastewater had an average nitrate - nitrogen $\left(\mathrm{NO}_{3}{ }^{-} \mathrm{N}\right)$ concentration of $21.64 \pm 0.60 \mathrm{mg} \mathrm{L}^{-1}$. $\mathrm{NO}_{3}^{-}-\mathrm{N}$ accumulates in aquaculture systems as a result of nitrification ${ }^{[36,37]}$. At HRTs of 6 and 12 days, the average $\mathrm{NO}_{3}{ }^{-} \mathrm{N}$ reductions from the controls and the compartments containing water hyacinth, water lettuce and parrot's feather were 25.6, 43.7, 41.8 and $34.5 \%$ and 25.0, 54.4, 52.9 and $50.9 \%$, respectively. The results of the statistical analyses are presented in Tables 14 and 15. Both plant type and HRT had significant effects on $\mathrm{NO}_{3}{ }^{-} \mathrm{N}$ reductions. The $\mathrm{NO}_{3}{ }^{-} \mathrm{N}$ removal was higher in the compartments containing water hyacinth followed by the compartments containing water lettuce and parrot's feather, although the differences between the three plants was small (Table 15). The $\mathrm{NO}_{3}{ }^{-} \mathrm{N}$ reductions increased with the longer retention time.

Jo et al. ${ }^{[8]}$ evaluated the potential of water lettuce and water hyacinth plants for removal of $\mathrm{NO}_{3}{ }^{-}-\mathrm{N}$ from an intensive, recirculating aquaculture system effluent over a 48 hour period and found that the $\mathrm{NO}_{3}{ }^{-} \mathrm{N}$ concentration in the wastewater was reduced from 21.4 to 17.4 and $17.9 \mathrm{mg} \mathrm{L}^{-1}$, respectively. Awuah et al. ${ }^{[25]}$ evaluated the potential use of water lettuce for pollutant removal from a low - strength, anaerobically treated domestic sewage and reported $\mathrm{NO}_{3}{ }^{-} \mathrm{N}$ reductions of $70 \%$ after 6 months of operation. DeBusk et al. ${ }^{[15]}$ evaluated the use of a water hyacinth based treatment system for nutrient removal from a secondarily treated municipal wastewater over a three month period and reported that the $\mathrm{NO}_{3}{ }^{-} \mathrm{N}$ concentration in the wastewater was reduced from 4.12 to $0.26 \mathrm{mg} \mathrm{L}^{-1}$. Dedes and O'Shaughnessy ${ }^{[14]}$ investigated the use of duckweed (Lemna minor) for treatment of domestic wastewater over 74 days under 5 different hydraulic retention times $(2.0,2.7,5.5,5.6$ and 11.7 days) and reported that the fraction of $\mathrm{NO}_{3}{ }^{-} \mathrm{N}$ removed ranged from 17 to $36 \%$ and increased with longer retention times.
Table 14: Results of a two-way ANOVA for $\mathrm{NO}_{3}^{-}-\mathrm{N}$ reductions as affected by plant type and hydraulic retention time

\begin{tabular}{lrrrrc}
\hline Source & DF & \multicolumn{1}{c}{ SS } & MS & F & P \\
\hline Total & 23 & 2939.74 & & & \\
Model & 7 & 2890.93 & & & \\
$\quad$ Plant type & 3 & 2086.67 & 695.558 & 228.02 & 0.000 \\
HRT & 1 & 532.04 & 532.042 & 174.42 & 0.000 \\
$\quad$ Plant type $\times$ HRT & 3 & 272.22 & 090.739 & 29.75 & 0.000 \\
Error & 16 & 048.81 & 003.050 & & \\
\hline
\end{tabular}

Differences are considered significant at the $\mathrm{p} \leq 0.05$ level $(95 \%$ confidence interval)

Table 15: Results of a Duncan's multiple range test for $\mathrm{NO}_{3}{ }^{-} \mathrm{N}$ reductions as affected by plant type and hydraulic retention time

\begin{tabular}{lcc}
\hline Parameter & $\begin{array}{c}\text { Average } \mathrm{NO}_{3}-\mathrm{N} \text { reduction } \\
(\%)\end{array}$ & $\begin{array}{c}\text { Duncan subsets } \\
(\alpha \leq 0.05)\end{array}$ \\
\hline Plant type & & \\
$\quad$ Control & 25.28 & $\mathrm{~A}$ \\
Water hyacinth & 49.05 & $\mathrm{~B}$ \\
Water lettuce & 46.35 & $\mathrm{~B}, \mathrm{C}$ \\
$\quad$ Parrots feather & 43.72 & $\mathrm{C}, \mathrm{D}$ \\
HRT (days) & & \\
6 & 36.39 & $\mathrm{~A}$ \\
12 & 45.81 & $\mathrm{~B}$ \\
\hline
\end{tabular}

Treatments with different numbers are significantly different at the $p$ $\leq 0.05$ level

$\mathrm{NO}_{3}{ }^{-} \mathrm{N}$ is not acutely toxic to fish. However, it should not be allowed to accumulate in aquaculture systems because chronic toxicity symptoms and algae and phytoplankton blooms may eventually develop ${ }^{[8,32]}$. Chronic toxicity symptoms associated with exposure to nitrate include: reduction in the oxygen carrying capacity of the blood, inability of organisms to maintain proper balance of salts, stunted growth and lethargy ${ }^{[41]}$. The average $\mathrm{NO}_{3}{ }^{-} \mathrm{N}$ concentrations in the final effluents from the hydroponics system ranged from 12.18 to $14.17 \mathrm{mg} \mathrm{L}^{-1}$ and from 9.87 to $10.62 \mathrm{mg} \mathrm{L}^{-1}$ at HRTs of 6 and 12 days, respectively. Poxton ${ }^{[32]}$ recommended that $\mathrm{NO}_{3}{ }^{-} \mathrm{N}$ concentrations do not exceed $50 \mathrm{mg} \mathrm{L}^{-1}$ in waters used for the culture of fish and shellfish. Waters suitable for reuse in aquaculture were produced.

Phosphate - Phosphorus: The aquaculture wastewater contained $4.49 \pm 0.18 \mathrm{mg} \mathrm{L}^{-1}$ phosphate - phosphorus $\left(\mathrm{PO}_{4}{ }^{3-}-\mathrm{P}\right)$. Phosphorus occurs in aquaculture wastewater primarily as soluble and insoluble phosphates in both organic and inorganic forms ${ }^{[33]}$. The main inorganic form is soluble orthophosphate, which exists in different states $\left(\mathrm{H}_{2} \mathrm{PO}_{4}{ }^{-}, \mathrm{HPO}_{4}{ }^{2-}\right.$, and $\left.\mathrm{PO}_{4}{ }^{3-}\right)$ depending on the $\mathrm{pH}$ of the medium ${ }^{[42]}$.

At HRTs of 6 and 12 days, the average $\mathrm{PO}_{4}{ }^{3-}-\mathrm{P}$ reductions from the controls and the compartments containing water hyacinth, water lettuce and parrot's 
feather were $38.4,66.2,65.0$ and $64.5 \%$ and $43.3,76.8$, 75.3 and $66.8 \%$, respectively. The results of the statistical analyses are presented in Tables 16 and 17. Both the plant type and the HRT had significant effects on $\mathrm{PO}_{4}{ }^{3-}-\mathrm{P}$ removal. The $\mathrm{PO}_{4}{ }^{3-}-\mathrm{P}$ removal was higher in the compartments containing water hyacinth followed by the compartments containing parrot's feather and water lettuce, although the difference between the latter two was not significant. The $\mathrm{PO}_{4}{ }^{3-}-\mathrm{P}$ reductions were influenced by hydraulic retention time and increased as HRT was increased.

Table 16: Results of a two-way ANOVA for $\mathrm{PO}_{4^{-}}{ }^{3-} \mathrm{P}$ reductions as affected by plant type and hydraulic retention time

\begin{tabular}{lrrrrr}
\hline Source & DF & \multicolumn{1}{c}{ SS } & MS & F & P \\
\hline Total & 23 & 4320.04 & & & \\
Model & 7 & 4094.39 & & & \\
$\quad$ Plant type & 3 & 3682.96 & 1227.65 & 87.05 & 0.000 \\
HRT & 1 & 362.70 & 362.70 & 25.72 & 0.000 \\
$\quad$ Plant type $\times$ HRT & 3 & 48.73 & 16.24 & 1.15 & 0.359 \\
$\quad$ Error & 16 & 225.65 & 14.10 & & \\
\hline
\end{tabular}

Differences are considered significant at the p 0.05 level $(95 \%$ confidence interval)

Table 17:Results of a Duncan's multiple range test for $\mathrm{PO}_{4}{ }^{3-}-\mathrm{P}$ reductions as affected by plant type and hydraulic retention time

\begin{tabular}{lcc}
\hline Parameter & $\begin{array}{c}\text { Average } \mathrm{PO}_{4}{ }^{3-}-\mathrm{P} \text { reduction } \\
(\%)\end{array}$ & $\begin{array}{c}\text { Duncan subsets } \\
(\alpha \leq 0.05)\end{array}$ \\
\hline Plant type & & \\
Control & 40.72 & $\mathrm{~A}$ \\
$\quad$ Water hyacinth & 70.92 & $\mathrm{~B}$ \\
$\quad$ Water lettuce & 64.17 & $\mathrm{C}$ \\
$\quad$ Parrots feather & 70.78 & $\mathrm{~B}$ \\
HRT (days) & & \\
$\quad 6$ & 57.76 & $\mathrm{~A}$ \\
12 & 65.53 & $\mathrm{~B}$ \\
\hline
\end{tabular}

Treatments with different numbers are significantly different at the $\mathrm{p}$ $\leq 0.05$ level

Cloris and Araujo $^{[43]}$ examined the use of a water hyacinth based system for tertiary treatment of domestic sewage and reported a $\mathrm{PO}_{4}{ }^{3-}-\mathrm{P}$ reduction of $88 \%$ over a 4 month period. Xu et al. ${ }^{[44]}$ evaluated the ability of a water hyacinth based treatment system for removal of nutrients from domestic wastewater and reported $\mathrm{PO}_{4}{ }^{3-}-\mathrm{P}$ reduction of $75-95 \%$. Jing et al. ${ }^{[26]}$ investigated the use of water lettuce for nutrient removal from an artificially prepared wastewater over a 30 day period and reported average $\mathrm{PO}_{4}{ }^{3-}-\mathrm{P}$ removal efficiencies in the controls and in the compartments containing water lettuce of 8.0, 33.3, 42.3 and $31.6 \%$ and $14.3,53.9,73.2$ and $55.6 \%$ at hydraulic retention times of 1, 2, 3 and 4 days, respectively.

The average $\mathrm{PO}_{4}{ }^{3-}-\mathrm{P}$ concentrations in the final effluents from the hydroponics system ranged from 1.52 to $1.59 \mathrm{mg} \mathrm{L}^{-1}$ and from 1.04 to $1.49 \mathrm{mg} \mathrm{L}^{-1}$ at
HRTs of 6 and 12 days, respectively. Toxicity from high levels of phosphorus has not been reported by aquaculturists ${ }^{[34]}$.

pH: The aquaculture wastewater had an average $\mathrm{pH}$ of $7.00 \pm 0.13$. At hydraulic retention times of 6 and 12 days, the $\mathrm{pH}$ of the final effluent leaving the system was $8.21,8.37,8.20$ and 8.24 and $8.53,8.49,8.37$ and 8.31 for the controls and compartments containing water hyacinth, water lettuce and parrot's feather, respectively.

Sooknah and Wilkie ${ }^{[9]}$ compared the potential of water hyacinth and water lettuce plants for reducing the nutrient content of an anaerobically digested dairy manure over 31 days and reported an initial $\mathrm{pH}$ of the anaerobically digested dairy manure of $7.81-7.91$ and final $\mathrm{pH}$ values of $8.50,8.32$ and 7.72 in the control and in the compartments containing water hyacinth and water lettuce, respectively. Kanabkaew and Puetpaiboon $^{[45]}$ examined the use lotus (Nelumbo nucifera) and hydrilla (Hydrilla verticillata) for pollutant removal from secondarily treated municipal wastewater at HRTs of 5.4 and 10.5 days and reported an initial $\mathrm{pH}$ of the wastewater of $7.3 \pm 0.2$ and final $\mathrm{pH}$ values in the effluent of 10.0, 7.7 and 10.5 and 10.0, 8.0 and 10.8 in the control and in ponds containing lotus and hydrilla, respectively. John ${ }^{[21]}$ investigated the use of water hyacinth for treatment of rubber factory $(\mathrm{pH}=$ 5.20) and palm oil mill effluents $(\mathrm{pH}=6.49)$ and reported $\mathrm{pH}$ values in the final effluent of $6.83,6.73$ and 6.85 at HRTs of 5, 10 and 15 days when water hyacinths were grown on undiluted raw rubber factory effluent and 7.49, 7.98 and 8.08 when water hyacinths were grown on an anaerobically treated palm oil mill effluent at HRTs of 10, 20 and 25 days, respectively.

According to Lawson ${ }^{[3]}$ and Meade ${ }^{[23]}$, the $\mathrm{pH}$ of waters used for the culture of fish and shellfish should range from 6.5 to 8.0. When the $\mathrm{pH}$ of the growth medium rises above 9.0 , it begins to adversely affect most aquatic species, and a $\mathrm{pH}$ in the range of $11.0-$ 11.5 is lethal to all species of fish ${ }^{[36]}$. When $\mathrm{pH}$ falls within the range of $5.0-6.0$, rainbow trout, salmonids and molluscs become rare, the rate of organic matter decomposition declines because the fungi and bacteria responsible for degradation are not acid tolerant, and most green algae, diatoms, snails and phytoplankton disappear ${ }^{[32]}$. Most fish eggs will not hatch when the $\mathrm{pH}$ of the surrounding environment reaches 5.0. Changes in water chemistry may also occur as a result of a decrease in $\mathrm{pH}^{[36]}$. Waters suitable for reuse in an aquaculture facility were not produced. 


\section{CONCLUSIONS}

During the experiment, the aquatic plants grew rapidly and appeared healthy with green color. At hydraulic retention times (HRTs) of 6 and 12 days, the average water hyacinth, water lettuce and parrot's feather yields were 83,51 and $51 \mathrm{~g}(\mathrm{dm}) \mathrm{m}^{-2}$ and 49,29 and $22 \mathrm{~g}(\mathrm{dm}) \mathrm{m}^{-2}$, respectively. The aquatic plants were able to significantly reduce the pollution load of the aquaculture wastewater. The TS, $\mathrm{COD}, \mathrm{NH}_{4}{ }^{+}-\mathrm{N}$, $\mathrm{NO}_{2}{ }^{-} \mathrm{N}, \mathrm{NO}_{3}{ }^{-}-\mathrm{N}$ and $\mathrm{PO}_{4}{ }^{3-}-\mathrm{P}$ reductions ranged from 21.4 to $48.0 \%$, from 71.1 to $89.5 \%$, from 55.9 to $76.0 \%$, from 49.6 to $90.6 \%$, from 34.5 to $54.4 \%$ and from 64.5 to $76.8 \%$, respectively and generally increased with longer retention times. Reductions were highest in compartments containing water hyacinth followed by compartments containing water lettuce and parrot's feather. In terms of $\mathrm{COD}, \mathrm{NO}_{3}{ }^{-} \mathrm{N}$ and $\mathrm{PO}_{4}{ }^{3-}-\mathrm{P}$, the effluent leaving the hydroponics system was suitable for reuse in aquaculture. However, the effluent had slightly high levels of $\mathrm{TS}, \mathrm{NH}_{3}-\mathrm{N}, \mathrm{NO}_{2}{ }^{-}-\mathrm{N}$ and $\mathrm{pH}$ after treatment.

\section{ACKNOWLEDGEMENTS}

The research was funded by Agricultural and AgriFood Canada.

\section{REFERENCES}

1. FAO. 2004. The State of World Fisheries and Aquaculture 2004. [online] Available: ftp:// ftp.fao.org/docrep/fao/007/y5600e/y5600e01.pdf [6 July 2005].

2. Kioussis, D. R., Wheaton, F. W. and Kofinas, P. 2000. Reactive nitrogen and phosphorus removal from aquaculture wastewater effluents using polymer hydrogels. Aquacultural Engineering, 23 (4): 315-332.

3. Lawson, T. B. 1995. Fundamentals of Aquacultural Engineering. Chapman \& Hall, New York, NY.

4. Schwartz, M. F. and Boyd, C. E. 1994. Effluent quality during harvest of channel catfish from watershed ponds. The Progressive Fish-Culturist, 56 (1): 25-32.

5. Adler, P. R., Harper, J. K., Takeda, F., Wade, E. M. and Summerfelt, S. T. 2000. Economic evaluation of hydroponics and other treatment options for phosphorus removal in aquaculture effluent. HortScience, 35 (6): 993-999.
6. Redding, T., Todd, S. and Midlen, A. 1997. The treatment of aquaculture wastewaters - a botanical approach. Journal of Environmental Management, 50 (3): 283-299.

7. Reddy, K. R. and DeBusk, T. A. 1987. State-ofthe-art utilization of aquatic plants in water pollution control. Water Science and Technology, 19 (10): 61-79.

8. Jo, J. Y., Ma, J. S. and Kim, I. B. 2002. Comparisons of four commonly used aquatic plants for removing nitrogen nutrients in the intensive bioproduction Korean (IBK) recirculating aquaculture system. Proceedings of the $3^{\text {rd }}$ International Conference on Recirculating Aquaculture, Roanoke, VA, 20-23 Jul 2000.

9. Sooknah, R. D. and Wilkie, A. C. 2004. Nutrient removal by floating aquatic macrophytes cultured in anaerobically digested flushed dairy manure wastewater. Ecological Engineering, 22: 27 - 42.

10. Schulz, C., Gelbrecht, J. and Rennert, B. 2003. Treatment of rainbow trout farm effluents in constructed wetland with emergent plants and subsurface horizontal water flow. Aquaculture, 217 (1-4): 207-221.

11. APHA. 1998. Standard Methods for the Examination of Water and Wastewater $20^{\text {th }}$ Edition. American Public Health Association, American Water Works Association and Water Environment Federation, Washington, DC.

12. ASA. 1982. Methods of Soil Analysis. Part 2: Chemical and Microbiological Properties $2^{\text {nd }}$ Edition. American Society of Agronomy, Inc. and Soil Science Society of America, Inc., Madison, Wisconsin.

13. Oron, G., Louw, R. W. and Porath, D. 1985. Wastewater recycling by duckweed for protein production and effluent renovation. Water Science and Technology, 17 (4-5): 803-817.

14. Dedes, J. G. and O'Shaughnessy, J. C. 1985. A bench-scale study of wastewater aquaculture using the duckweed, Lemna minor. Environmental Engineering, Proceedings of the 1985 Specialty Conference, Boston, MA. p. 771-778.

15. DeBusk, T. A., Williams, L. D. and Ryther, J. H. 1983. Removal of nitrogen and phosphorus from wastewater in a water hyacinth based treatment system. Journal of Environmental Quality, 12 (2): 257-262. 
16. Wen, L. and Recknagel, F. 2002. In situ removal of dissolved phosphorus in irrigation drainage water by planted floats: preliminary results from growth chamber experiment. Agriculture, Ecosystems and Environment, 90 (1): 9-15.

17. Chen, S. and Stechey, D. 1994. Suspended solids control in recirculating aquaculture systems. In: Timmons, M. B. and Losordo, T. M. (editors). Aquaculture Water Reuse Systems: Engineering Design and Management. Elsevier, New York, NY.p. $61-100$.

18. Cripps, S. and Bergheim, A. 2000. Solids management and removal for intensive land-based aquaculture production systems. Aquacultural Engineering, 22 (1-2): 33-56.

19. Pillay, T. V. R. 1992. Aquaculture and the Environment. Fishing News Books, Oxford, England.

20. Nuttall, P. M. 1985. Uptake of phosphorus and nitrogen by Myriophyllum aquaticum (Velloza) Verd. growing in a wastewater treatment system. Australian Journal of Marine and Freshwater Research, 36 (4): 493-507.

21. John, C. K. 1985. Treatment of argo-industrial wastes using water hyacinth. Water Science and Technology, 17 (4-5): 781-790.

22. Cripps, S. and Kumar M. 2003. Environmental and Other Impacts of Aquaculture. In: Lucas, J. S. and Southgate, P. C. (editors). Aquaculture: Farming Aquatic Animals and Plants. Blackwell Publishing, Oxford, England. p.74-99.

23. Meade J. W. 1989. Aquaculture Management. Van Nostrand Reinhold, New York, NY.

24. Viadero, R. C., Cunningham, J. H., Semmens, K. J. and Tierney A. E. 2005. Effluent and production impacts of flow-through aquaculture operations in West Virginia. Aquacultural Engineering, 33 (4): $258-270$.

25. Awuah, E., Oppong-Peprah, M., Lubberding, H. J. and Gijzen, H. J. 2004. Comparative performance studies of water lettuce, duckweed, and algal-based stabilization ponds using low-strength sewage. Journal of Toxicology and Environmental Health Part A, 67 (20-22): 1727-1739.

26. Jing, S.-R., Lin, Y.-F., Wang, T.-W. and Lee, D.Y. 2002. Microcosm wetlands for wastewater treatment with different hydraulic loading rates and macrophytes. Journal of Environmental Quality, 31: $690-696$.
27. Islam, M. 2005. Nitrogen and phosphorus budget in coastal and marine cage aquaculture and impacts of effluent loading on ecosystem: review and analysis towards model development. Marine Pollution Bulletin, 50 (1): 48-61.

28. Holmer, M., Duarte, C. M., Heilskov, A., Olesen, B. and Terrados, J. 2003. Biogeochemical conditions in sediments enriched by organic matter from net- pen fish farms in the Bolinao area, Philippines. Marine Pollution Bulletin, 46 (11): 1470-1479.

29. Wu, R. S. S. 1995. The environmental impact of marine fish culture: towards a sustainable future. Marine Pollution Bulletin, 31 (4-12): 159-166.

30. Gowen, R. J., Weston, D. P. and Ervik, A. 1990. Aquaculture and the Benthic Environment: A Review. In: Cowey, C. B. and Cho, C. Y. (editors). Nutritional Strategies \& Aquaculture Waste. Fish Nutrition Research Laboratory, Guelph, Ontario. p. 187-205.

31. Porath, D. and Pollock, J. 1982. Ammonia stripping by duckweed and its feasibility in circulating aquaculture. Aquatic Botany, 13 (2): 125-131.

32. Poxton, M. 2003. Water Quality. In: Lucas, J. S. and Southgate, P. C. (editors). Aquaculture: Farming Aquatic Animals and Plants. Blackwell Publishing, Oxford, England. p.47-73.

33. EPA. 2000. Constructed Wetlands: Treatment of Municipal Wastewaters. [online] Available: http://www.epa.gov/nrmrl/pubs/625r99010/625r99 010.pdf [2005 June 11].

34. Stickney, R. R. 1994. Principles of Aquaculture. John Wiley and Sons, Inc., New York, NY.

35. Randall, D. J. and Tsui, T. K. N. 2002. Ammonia toxicity in fish. Marine Pollution Bulletin, 45 (112): $17-23$.

36. Poxton, M. G. and Allouse, S. B. 1982. Water quality criteria for marine fisheries. Aquacultural Engineering, 1 (3): 153-191.

37. Ackefors, H., Huner, J. V. and Konikoff, M. 1994. Introduction to the General Principles of Aquaculture. Food Products Press, New York, NY.

38. Princic, A., Mahne, I., Megusar, F., Paul, E. A. and Tiedje, J. M. 1998. Effects of $\mathrm{pH}$ and oxygen and ammonium concentrations on the community structure of nitrifying bacteria from wastewater. Applied and Environmental Microbiology, 64(10): $3584-3590$. 
39. Jensen, F. B. 2003. Nitrite disrupts multiple physiological functions in aquatic animals. Comparative Biochemistry and Physiology Part A, 135 (1): $9-24$.

40. Madison, B. N. and Wang, Y. S. 2006. Haematological responses of acute nitrite exposure in walleye (Sander vitreus). Aquatic Toxicology, 79: $16-23$.

41. CCME. 1999. Canadian Water Quality Guidelines for the Protection of Aquatic Life. Canadian Council of Ministers of the Environment, Winnipeg, Manitoba.

42. Mitsch, W. J. and Gosselink, J. G. 2000. Wetlands. John Wiley and Sons, Toronto, ON.
43. Cloris, M. and Araujo, H. 1987. Use of water hyacinth in tertiary treatment of domestic sewage. Water Science and Technology, 19(10): 11-17.

44. Xu, H., Wang, B., Yang, Q. and Liu, R. 1992. Treatment o domestic sewage in macrohydrophyte ponds. Water Science and Technology, 26(7-8): $1639-1649$.

45. Kanabkaew, T. and Puetpaiboon, U. 2004. Aquatic plants for domestic wastewater treatment: lotus (Nelumbo nucifera) and hydrilla (Hydrilla verticillata) systems. Songklanakarin Journal of Science and Technology, 26(5): 749 - 756. 